\title{
A case study for irrigation modernisation:
}

\section{Scenario analysis}

\author{
Playán, E. ${ }^{1}$, Slatni, A. ${ }^{2}$, Castillo, R. ${ }^{3}$ and Faci, J. M. ${ }^{4}$
}

\section{$\underline{\text { Abstract }}$}

Surface irrigation simulation models have seldom been used in engineering practise, and district modernisation is not an exception. Surface irrigation evaluations were performed in the Almudévar irrigation district to obtain the parameters required for surface irrigation modelling. The total district irrigated area was divided into 92 design units, for which a characteristic blocked-end border was defined. Simulation was used to establish the current irrigation performance in each design unit, and district performance contour maps were built. Irrigation performance was characterised using potential application efficiency, with an average of 54\%, and irrigation time, averaging $6 \mathrm{hr} \mathrm{ha}{ }^{-1}$. Simulated potential application efficiency of the low quarter was similar to the Seasonal Irrigation Performance Index (an estimate of irrigation efficiency) presented in the companion paper. A set of seven modernisation scenarios was defined. Two

\footnotetext{
${ }^{1}$ (O) Dept. Genetics and Plant Production, Lab. for Agronomy and the Environment (DGA-CSIC). Estación Experimental de Aula Dei, CSIC. Apdo. 202. 50080 Zaragoza, Spain. Email: playan@eead.csic.es

${ }^{2}$ Institut National de Recherches en Genie Rural, Eaux et Forêt (INGREF). B.P. 10, 2080 Ariana, Tunisie.

${ }^{3}$ CINGRAL, Consultora de Ingeniería Rural. Santiago, 27, 5 Izda., 50003, Zaragoza, Spain

${ }^{4}$ Dept. Soils and Irrigation, Lab. For Agronomy and the environment (DGA-CSIC). Servicio de Investigación Agroalimentaria, DGA. Apdo. 727. 50080 Zaragoza, Spain. Email: faci@syrsig.mizar.csic.es
} 
strategies were identified to improve the potential application efficiency in the scenarios: increase the irrigation discharge into the current blocked-end borders and / or substitute the current system with a solid set sprinkler irrigation system. The performance of each scenario was estimated using irrigation models to determine efficiency, water conservation and irrigation time. The modernisation investment costs were estimated and compared to the performance of each scenario. The best results (potential application efficiency of $77 \%$, reduced water allocation by $14.410^{6} \mathrm{~m}^{3}$ year $^{-1}$ ) were obtained by a combination of blocked-end irrigation with a discharge of $200 \mathrm{~L} \mathrm{~s}^{-1}$ and sprinkler irrigation in the areas where surface irrigation efficiency could not attain $50 \%$. The investment cost for this scenario was 3,932 Euro ha ${ }^{-1}$. More expensive scenarios did not guarantee better performance.

Keywords: surface, irrigation, district, modernisation, simulation.

\section{Introduction}

A companion paper (Faci et al., 1999), characterised water use patterns in the Almudévar irrigation district. The district is located in the Huesca province, in Northeastern Spain. The irrigation district surface is 3,579 ha. The on-farm irrigation systems are, almost exclusively, blocked-end borders. The conveyance system, composed of a dense network of canals and ditches, is unable to meet farmers' water demand at the peak of the season, inducing localised water stress. The study was based on an analysis of district maintained water records. A hydrological approach was followed in the above-referenced paper: water allocation was compared to crop water requirements using a seasonal irrigation performance index (SIPI). The purpose of that work was to analyse the current water distribution and water application procedures in Almudévar. 
The conclusions of the analysis will be used in this paper to establish modernisation scenarios of the district. Relevant limitations were found in both the management and structural aspects of the district.

Water delivery procedures in Almudévar are elaborate and enforce water conservation. Some management measures, such as extending the limited rate arranged delivery schedule (Clemmens, 1987) practised in $80 \%$ of the area to the whole district could improve irrigation efficiency by themselves. Nevertheless, we believe that most of the actual management practices are a consequence of the irrigation structures and could not be improved without modernising the structures. Among the most relevant structural limitations identified by Faci et al. (1999) are the small ditch capacity and the lack of in-line district reservoirs. These limitations are responsible for frequent crop water stress, low irrigation efficiency, and use of crops with low economic revenue. Other factors, such as land tenure or soil type, were shown to play an important role on irrigation efficiency.

In the present work, only structural aspects will be introduced in the modernisation scenarios. The technical evaluation of the scenarios will assume that the management practices are optimum in each case. Therefore, the actual implementation of a modernisation plan would only attain its potential if a Management Improvement Program (Dedrick et al., 1993) was established in the district.

Farmers in Almudévar are currently facing a strategic decision regarding their irrigation structures: improving the current surface irrigation systems or switching to a solid set sprinkler irrigation system (Comunidad de Regantes de Almudévar, 1997). To 
make this decision, farmers need to consider factors such as investment costs, irrigation water costs, energy costs, labour requirements, effects on crop yield and prospective crops. All these factors should be considered to compute the net benefit of the district modernisation. Net benefit estimation lies beyond the objectives of this work, for it would require an in-depth economic analysis and additional technical data on crops, farming practices and irrigation decision making. Instead, we will focus on the relationships between the investment costs and some performance indexes, like efficiency, irrigation labour requirements and water conservation. These indexes should express the interest of irrigation professionals, farmers and public planners on the modernisation project.

In this study, simulation will be used to diagnose the current irrigation performance and assess decision making in the modernisation of the Almudévar irrigation district. Surface irrigation models have been available for decades now, but their applications to real life design and management of surface irrigation systems have been scarce. Sprinkler irrigation performance is less dependent on soil characteristics than surface irrigation, and therefore its performance will be estimated from the literature for the environmental conditions of Almudévar.

The purpose of this paper is to develop and apply a methodology for studying modernisation scenarios in an irrigation district. From a conceptual standpoint, it is necessary to establish the current performance level prior to the definition of any rehabilitation scenario. Irrigation simulation models can be very useful once the input data have been collected. A detailed analysis of the district (as provided in the companion paper) and a series of irrigation evaluations are required for this purpose. A 
scenario analysis is a very appropriate procedure to evaluate modernisation policies that can be extended to other districts sharing similar problems.

\section{Materials and methods}

\section{Irrigation evaluation}

The purpose of the irrigation evaluations was to measure irrigation performance and to provide infiltration data for surface irrigation simulation (Slatni, 1996). A total of 15 irrigation evaluations (Merriam and Keller, 1978) were performed in the study area. The test fields were chosen among the borders irrigated in the district each day. Selected test fields had a regular geometry and were much longer than wide. During the evaluations, farmers performed their normal irrigation practices.

The border dimensions and slope were determined using a topographic station. To establish the field slope and the quality of land levelling, soil surface elevation was surveyed at a series of points separated $10 \mathrm{~m}$ along each border. The field slope was obtained by regression. The deviations between the observed elevations and the regression line were used to estimate the quality of land levelling. The standard deviation of the elevation deviates (SDe) was used for this purpose, considering that a SDe of $1 \mathrm{~cm}$ is representative of recently laser levelled fields (Bucks and Hunsaker, 1987).

Irrigation discharge was computed using two in situ measurements of flow cross-sectional area and velocity. Flow velocity was measured using a propeller meter. 
The times of advance and recession were recorded for locations separated $20 \mathrm{~m}$ along the border.

Flow depth was measured at the end of the advance phase, just before cut off, at a location close to the upstream end of the border (about $10 \mathrm{~m}$ downstream). At this location discharge can be assumed to be independent of the infiltration rate, and the inlet turbulence does not affect flow depth measurement. Depth measurements were performed approximately every $2 \mathrm{~m}$ across the border and averaged. Infiltration measurements were obtained only in selected evaluations, to approximate the value of the infiltration parameters of a Kostiakov equation (Walker, 1989).

The roughness and infiltration parameters corresponding to each evaluation were obtained from flow depth and the advance-recession diagram. For this purpose, a hydrodynamic surface irrigation model (Walker, 1993) was run iteratively until a reasonable agreement was obtained between the observed and simulated events. The process consisted of estimating first the roughness (characterised by a value of Manning $\mathrm{n})$. The value of $\mathrm{n}$ was adjusted to obtain agreement between the observed and simulated flow depth at the location and time of the measurement. Based on the infiltration experiments, initial guesses were provided for the Kostiakov parameter $\mathrm{k}$ and the exponent a. These values were adjusted to match the advance-recession curves. When simulation reproduced the terminal upstream depth and the advance-recession diagram, the adjusting process was concluded.

Infiltration classes were identified after inspection of the infiltration curves obtained for the irrigation evaluations and the location of the evaluations on the soil 
map. The curve corresponding to each infiltration class was obtained using regression on the infiltration curves represented by the class.

Uniformity was estimated using the Distribution Uniformity concept (Burt et al., 1997):

$$
\mathrm{DU}=\frac{\text { Average low quarter depth }}{\text { Average irrigation depth }} 100
$$

Application Efficiency (Burt et al., 1997) was estimated according to the equation:

$$
\mathrm{AE}=\frac{\text { Average depth of irrigation water contributing to target }}{\text { Average depth of irrigation water applied }} 100
$$

where the target depth was considered equal to the management allowable depletion (MAD, mm), as defined by Merriam and Keller (1978) and characterised in the companion paper.

\section{Design units: characterisation of irrigation related properties}

One of the goals of this research is to provide objective ways to evaluate modernisation scenarios based on their impact on water use and cost. Water use in surface irrigation is often evaluated using simulation models. These models are applied to irrigation units: one basin, one border or one furrow. In most irrigation districts there are literally thousands of farms, each of them containing several irrigation units. Application of simulation techniques to each irrigation unit in a study area would be unmanageable. 
The solution adopted in this work was to define irrigation design units (Slatni, 1996). The design units contain several plots with similar irrigation properties, among them, farm and border size, soil type (infiltration and management allowable depletion), slope, and irrigation discharge. These units are often supplied by the same ditch or canal, and are surrounded by watercourses or roads. Unit size depends on the desired level of detail in the evaluation of the alternatives.

For each design unit, a series of properties must be defined. These properties characterise the irrigation unit (the characteristic border, in this case) of the design unit. These properties include:

- Management allowable depletion. These data were obtained from the map presented in Figure 4 of the companion paper (Faci et al., 1999).

- Border length and width. These variables were obtained from aerial photographs, in which the design units were delineated. The number of borders was visually determined for each unit, and so was the average border width. This variable was subjected to less variability than the border length, which was computed from the unit area, the number of borders and their width.

- Slope. The longitudinal slope was measured at the borders where irrigation evaluations were performed.

- Irrigation discharge. These data were supplied by the district management, and were equal to the capacity of the irrigation ditches supplying each design unit. This assumption implies that seepage, leakage or theft losses were not considered in the study. 
- Infiltration. The soil unit in which the design unit is located is characterised by an infiltration class obtained from the irrigation evaluations.

\section{Identifying and evaluating modernisation scenarios}

Seven scenarios were considered for the modernisation of the Almudévar district. These were chosen based on the analysis of the current irrigation practice performed in the companion paper. The scenarios concentrated on the farmers' interest to reduce the time devoted to irrigation and on the social interest to increase irrigation efficiency. The description of the scenarios follows:

- Scenario I: Blocked end border irrigation with a discharge of $50 \mathrm{~L} \mathrm{~s}^{-1}$ (below the current average discharge of $80 \mathrm{~L} \mathrm{~s}^{-1}$ ). This scenario, presumably worse than the current situation, is provided for comparison.

- Scenario II: Blocked end border irrigation with a discharge of $100 \mathrm{~L} \mathrm{~s}^{-1}$.

- Scenario III: Blocked end border irrigation with a discharge of $150 \mathrm{~L} \mathrm{~s}^{-1}$.

- Scenario IV: Blocked end border irrigation with a discharge of $200 \mathrm{~L} \mathrm{~s}^{-1}$.

- Scenario V: The design units with efficiency under 50\% in scenario IV (1,140 ha) will have their length reduced by a half.

- Scenario VI: The design units with efficiency over 50\% in scenario IV (1,140 ha) will be surface irrigated. The rest will be sprinkler irrigated.

- Scenario VII: All the district will be sprinkler irrigated. 
In all scenarios the projected irrigation delivery schedule is limited rate arranged for surface irrigation and limited rate demand for sprinkler irrigation (Clemmens, 1987). A future crop distribution of 50\% corn, 25\% alfalfa and 25\% wheat was considered.

\section{Irrigation modelling}

The same model used for the surface irrigation evaluations was applied to simulate the modernisation scenarios. The variables used for design were the inflow discharge and the border length.

Increasing the irrigation discharge effectively reduces the time of advance and therefore decreases the non-uniformity induced by differences in advance time. However, using very large discharges can result in poor water management, because application efficiency becomes very sensitive to the time of cut off. The time of cut off that yields optimum efficiency is bracketed by incomplete irrigation and overirrigation at the downstream end. This time of cut off is always smaller than the time of advance. When the discharge is very large (in relation to the border size) a minute can make a significant difference in uniformity and efficiency, and this is not a situation suitable for practical applications. This circumstance actually sets an upper limit for the irrigation discharge. In this work, $200 \mathrm{~L} \mathrm{~s}^{-1}$ was used for this purpose.

A series of simulations was carried out with all parameters fixed, except for the time of cut off. The time of cut off was modified until the simulated average low-quarter depth $\left(d_{\mathrm{lq}}\right)$ matched the target irrigation depth, which was set equal to the soil MAD. 
The resulting application efficiency corresponds to the Potential Application Efficiency of the low quarter (PAE $\mathrm{Pq}_{\mathrm{q}}$ ), as defined by Burt et al. (1997):

$$
\mathrm{PAE}_{\mathrm{lq}}=\frac{\text { Average depth of irrigation water contributing to target }}{\text { Average depth of irrigation water applied such that } \mathrm{d}_{\mathrm{lq}}=\text { target }} 100
$$

$\mathrm{PAE}_{\mathrm{lq}}$ was computed for the current irrigation system and for each modernisation scenario.

The irrigation discharge is a key variable to manipulate during the design process, for it has an important effect on irrigation performance and irrigation time. Reducing the irrigation set time will surely meet the farmers' goals. An alternative way to increase irrigation performance in the presence of high infiltration is to reduce the border length. However, farmers prefer not to shorten irrigation runs, because it hinders machinery operation. In this work border length has been used as a variable only for those design units not attaining a 50\% application efficiency even for the largest simulated discharge.

A $\mathrm{PAE}_{\mathrm{lq}}$ was computed for each individual design unit. These values were then used to compute a weighted average $\mathrm{PAE}_{\mathrm{lq}}$ for each modernisation scenario. No attempt was made to simulate the performance of sprinkler irrigation systems. Instead, average values of application efficiency (67\%) and distribution uniformity (82\%) were selected from the literature as typical of solid sets in the environmental conditions of Almudévar (Cuenca, 1989). 


\section{Dimensioning district in-line reservoirs}

Reducing the irrigation time reduces the time farmers need to dedicate to irrigation practices. The farmers and district management are currently interested in switching from the current 24 hour-a-day operation to a 12 hour a day operation (in which water orders would only be serviced between 8 a.m. and 8 p.m.). This goal can only be accomplished if the irrigation time is reduced by more than one half, since the district presently operates at full conveyance capacity at the peak of the irrigation season. Since water is delivered to the district 24 hours a day, reservoirs would be required with enough capacity to store night water and deliver twice the canal turnout discharge during the 12 daylight hours. These reservoirs are often referred to as "night reservoirs".

Presently, the district has no reservoirs and therefore their construction is considered a priority. The modernisation cost will be estimated considering construction of night reservoirs for surface irrigation and four-day capacity reservoirs for sprinkler irrigation (a common design criterion in the area). The design of all reservoirs was based on a peak water demand corresponding to the $20 \%$ return probability year.

\section{Assessing scenario cost and performance}

Evaluation of the modernisation scenarios will compare the investment cost on one side, and a set of performance variables on the other. Costs will be computed in Euros, the European currency, and expressed per unit area (Euro ha ${ }^{-1}$ ). Different factors were considered in the computation of the modernisation cost of surface and sprinkler 
irrigation systems. The costs associated with each irrigation system are presented in Table 1. For surface irrigation, the costs are due to conveyance systems and reservoirs. A preliminary analysis of the construction needs indicated the convenience to use low pressure concrete pipes. The pipe diameters used would be $400 \mathrm{~mm}$ for scenario I, 500 $\mathrm{mm}$ for scenario II, and $600 \mathrm{~mm}$ for scenarios III to VI. The construction cost also includes gates, diversion checks and discharge measurement devices. Reservoirs will be constructed using locally extracted clay materials. Sprinkler irrigation costs considered the on-farm buried solid set and the pressurised water supply network (pumping stations, reservoirs, pipes and valves).

Among the possible performance variables, three were chosen. The first is irrigation efficiency. This index is of great significance for water consultants, but does not have a direct meaning that a public planner can appreciate. This is the reason why a second water performance was used: the amount of water saved by the modernisation project. Strictly speaking, if evapotranspiration is kept constant in the district, no real water savings will be obtained at a watershed scale. Nevertheless, the water not diverted to the district will remain stored at the main project reservoir. The benefits of these water savings also refer to water quality. In this connection, the return flows of the Almudévar irrigation district have been reported to convey significant loads of salts (mainly calcium sulphate) and nitrogen fertilisers (Quílez et al., 1987; Isidoro et al. 1997).

Irrigation simulations on the 92 design units produced a set of irrigation times and potential application efficiencies characteristic of one irrigation event in the district. In order to compute the gross water requirements of the irrigation district, we assume 
that the seasonal irrigation efficiency (Burt et al., 1997) is equal to the $\mathrm{PAE}_{\mathrm{lq}}$. For this hypothesis to be reasonable, farmers should develop their irrigation operations according to an appropriate irrigation schedule.

Water conservation was evaluated in terms of the seasonal volume of water saved in a year with average climatic conditions. The seasonal gross water requirements were computed for the current state and for each scenario dividing the seasonal net irrigation requirements by the average $\mathrm{PAE}_{\mathrm{lq}}$. Water savings were computed by comparing the current seasonal gross water requirements for each design unit with the requirements of each scenario. The difference between them, multiplied by the area of the design unit yields a volume of water. When this operation is repeated for each unit, the cumulative volume indicates the total expected water savings.

The third performance index, the irrigation time, is directed to the farmers. The irrigation time is obtained by simulation for each design unit. The output of the model is irrigation time for the representative border, and has to be divided by the border area so that the irrigation time is expressed in hours per hectare. Area weighing was used to obtain averages of the three performance indexes for each scenario.

\section{$\underline{\text { Results and discussion }}$}

\section{Irrigation evaluation}

Irrigation evaluations are summarised in Table 2. Since irrigation evaluations are easier to conduct with shorter crops, most evaluations were performed on alfalfa fields. 
The rest of the evaluation tests were performed on corn fields. The soil depth ranged from $40 \mathrm{~cm}$ (the high platforms) to $120 \mathrm{~cm}$ (the valley bottoms). The average soil depth was $89 \mathrm{~cm}$. A soil depth map for the Almudévar irrigation district is presented in Figure 2 of the companion paper (Faci et al., 1999).

The slope varied widely in the area, with an average of $0.80 \%$. A detailed slope survey on the district showed that most of the properly managed borders had slopes in the vicinity of $0.50 \%$. Farmers using small discharges (as in evaluations 8 and 11) often increase the border slope to reduce irrigation time. In evaluation 4, the border had two slopes: a large slope upstream, to accelerate advance, and a small slope downstream, to avoid localised waterlogging. The border area ranged from 0.2 to 2.2 ha, while the border length ranged from 103 to $380 \mathrm{~m}$. Evaluation 11 corresponded to a marginal border, where the irrigation system was more properly "wild flooding".

Irrigation discharge averaged $69 \mathrm{~L} \mathrm{~s}^{-1}$, slightly under the reported average service capacity of the water distribution network. The variability in the irrigation area, discharge and other irrigation related properties resulted in times of cut off ranging from 61 to $500 \mathrm{~min}$ (with an average of $219 \mathrm{~min}$ ). As for the quality of land levelling, in most of the evaluated borders the SDe ranged between 1 and $2 \mathrm{~cm}$, while in five cases SDe was larger, with values up to $3.9 \mathrm{~cm}$. The average SDe was $1.99 \mathrm{~cm}$, a value that indicates frequent use of Laser levelling in most farms.

The values for Manning $\mathrm{n}$ and the infiltration parameters $\mathrm{k}$ and a were obtained using the hydrodynamic model. Roughness in corn ranged from 0.04 to 0.06 , depending on the state of the soil and the crop. The range for alfalfa was wider: between 0.10 and 
0.29. This was primarily due to the crop height, but also to planting density. The variability in the infiltration parameters was very large: the value of $\mathrm{k}$ ranged from 0.004 to $0.034 \mathrm{~m} \mathrm{~min}^{-\mathrm{a}}$, while a ranged from 0.20 to 0.50 . The average values of the infiltration parameters $\mathrm{k}$ and a (obtained by regression using data from all the evaluations) were $0.015 \mathrm{~min}^{-\mathrm{a}}$ and 0.38 , respectively.

The distribution uniformity was often very large, in the $80-100 \%$ range, with a minimum of $58 \%$ and an average value of $89 \%$. As for efficiency, the results show more variation, induced by the differences in management allowable depletion. Efficiencies are uniformly distributed in the 29-90\% range. The average application efficiency among the 14 complete evaluations was $62 \%$.

\section{Design units: characterisation of irrigation related properties}

The properties that characterise the design units were presented in thematic maps to assist design unit delineation. Infiltration could not be mapped because only fourteen measurements were available. A soil map (Torres, 1983) was used instead for mapping infiltration. The irrigation evaluations were used to define infiltration properties for the soil unit in which the tests were conducted. Evaluations 4 and 7 were excluded from this analysis because their infiltration curves were very different from the other infiltration curves in the same soil unit. Figure 1 presents the remaining twelve infiltration curves (infiltration depth, $\mathrm{Z}$ vs. time). Considering the 10 soil units, the genetic relationships between them, and the similarity between the infiltration curves, four infiltration classes were defined (see Figure 1 for the infiltration parameters and curves corresponding to each class). Therefore, each infiltration class was used to 
represent similar soil units in the district. Infiltration classes I and II are representative of the high platforms located mainly on the Northeast of the district. Infiltration class IV is typical of the valley bottoms. Finally, infiltration class III is a transitional class between the platforms and the valley bottoms.

District design units are presented in Figure 2. The resulting 92 units respect the main landscape features, the soil units and the water courses. The area of these units ranges from 12 to 92 ha. Two variables were considered uniform in the whole district: border slope and roughness. A value of 0.50 \%o was set for border slope. This assumption is reasonable, since the adopted value corresponds to the average of the slope measurements. For Manning n, a value of 0.12 was adopted to represent the average conditions for different crops and development stages. This value corresponds to a weighed average of the characteristic values for the different crops.

\section{Estimated current district performance}

Figure 3 presents a $\mathrm{PAE}_{\mathrm{lq}}$ contour map of the district in the current conditions. Areas of high efficiency can be identified along valley bottoms surrounding the Violada and Artasona creeks. In these areas, the management allowable depletion is higher than in other district areas and infiltration is moderate (class IV). For the design units located in the valley bottoms, irrigation efficiency is in the vicinity of $80 \%$, a value that can be considered satisfactory and characteristic of properly designed and managed surface irrigation systems. In the high platforms, the situation is very different, with average efficiencies of about 30-40\%. Low management allowable depletion coupled with large 
infiltration results in a combination that yields poor surface irrigation performance (Walker, 1989).

The district averaged $\mathrm{PAE}_{\mathrm{lq}}$ is $54 \%$. This value contrasts with the average $\mathrm{AE}$ obtained from the irrigation evaluations: $62 \%$. The difference between those two values seems to be too large to be due to differences in methodology or sampling density. Since the selection of the borders to be evaluated was not fully random (borders were sought that had a particular geometry), it seems possible that borders with better than average design and management were selected for evaluation purposes.

Figure 3 can also be compared with Figure 11 from the companion paper (Faci et al., 1999). In the latter figure, the SIPI (Seasonal Performance Irrigation Index) is also higher along the creeks and lower in the platforms. The average values between the two maps are difficult to compare. However, the SIPI reported in the above reference was in some areas very large, indicating crop water stress, a factor not considered in the present study. Comparison between potential application efficiency and SIPI is best when the corn-based SIPI is used (Figure 10a of the companion paper), because corn farmers are more careful about water stress. The $\mathrm{PAE}_{\mathrm{lq}}$ contour map is very similar to the MAD contour map (Figure 4 in the companion paper). Management allowable depletion can be the major limiting factor to application efficiency in surface irrigation.

Average $\mathrm{DU}_{\mathrm{lq}}$ computed for each design unit was 89\% (data not presented), which can be considered high. This number agrees with the average uniformity obtained from the irrigation evaluations. The discrepancy implied by a high uniformity and low efficiency can be explained by the low MAD values characteristic of large areas of the 
district. If the MAD is low, the $\mathrm{PAE}_{\mathrm{lq}}$ will be poor, even if the $\mathrm{DU}_{\mathrm{lq}}$ is high (Walker, 1989).

Irrigation time contours are presented in Fig. 4. From the figure, the average irrigation time for the district is $350 \mathrm{~min} \mathrm{ha}^{-1}$. Irrigation time is particularly large on the West side of the district, an area with very large infiltration rates. This map quantifies one of the clearest farmers' perception of the irrigation district: the high economic cost of the labour devoted to irrigation.

\section{Performance of the modernisation scenarios}

Simulation results for each modernisation scenario are summarised in Table 3. In scenarios I through IV, increasing the discharge by a ratio of four decreased irrigation time by a ratio of 6.2 . Scenario III ( $\left.150 \mathrm{~L} \mathrm{~s}^{-1}\right)$ has an irrigation time of 124 min ha ${ }^{-1}$, less than one half of the current irrigation time (350 min ha ${ }^{-1}$ ). This means that in scenarios III-VI a daily 12 hour irrigation operation would be possible. Actually, scenario II would meet this requirement except probably for the periods of peak irrigation demand. As previously discussed, performance of scenario I will be in all senses worse than the current performance. Irrigation time is reduced from scenario IV to scenario $\mathrm{V}$ due to the shortening of the borders in areas characterised by poor application efficiency. In scenarios VI and VII, using sprinkler irrigation, the irrigation time is not considered in the analysis. State of the art sprinkler irrigation systems include automation devices that make their labour requirements non relevant when compared to surface irrigation systems. 
Potential application efficiency increases steadily with increasing discharge, attaining an average value of $67 \%$ for scenario IV. This value is similar to the estimated solid set sprinkler application efficiency. Scenario V increases efficiency to $71 \%$, while scenario VI, combining both irrigation systems, attains the highest efficiency (77\%). In surface irrigation, distribution uniformity increases with discharge (although the starting uniformity level was high).

The projected improvements in application efficiency can be observed in figures 5 and 6, which present $\mathrm{PAE}_{\mathrm{lq}}$ contour maps for scenarios IV and VI, respectively. Increasing the irrigation discharge to $200 \mathrm{~L} \mathrm{~s}^{-1}$ results in very high potential application efficiencies in the valley bottoms. In the high platforms, located in the Northeast of the district (with infiltration classes I and II and MAD in the vicinity of $50 \mathrm{~mm}$ ), the resulting $\mathrm{PAE}_{\mathrm{lq}}$ 's are only moderate, with low values just over $20 \%$. The only way to maintain the irrigation system and increase the potential application efficiency would be to decrease the border length (scenario V), a measure more academic than practical in the context of the Almudévar Irrigation district. In scenario VI (Fig. 6), potential application efficiency averages 77\%, a value well over the estimated average efficiency of solid set irrigation systems in Almudévar.

Table 4 presents the results of a series of computations related to irrigation and reservoir volumes. The gross irrigation requirement in Almudévar at the present time is estimated as $48.410^{6} \mathrm{~m}^{3}$ (corresponding to a water depth of 1,353 mm). Increasing the potential application efficiency reduces this volume and results in reduced irrigation diversions. The magnitude of these savings reaches a maximum for scenario VI, with 14.4 $10^{6} \mathrm{~m}^{3}$ (403 mm), a very considerable amount of water. The capacity of the 
required night reservoirs decreases as efficiency increases. This is actually one of the most tangible consequences of improving application efficiency: no storage or conveyance capacity are needed for the volume of water that would be lost on-farm.

The modernisation costs (Table 5) range between 2,402 and 5,195 Euro ha ${ }^{-1}$. Between scenarios I and III cost increases with the service discharge. Between scenarios III and IV cost slightly decreases because both scenarios use the same pipe diameter and scenario IV requires a smaller reservoir capacity. Reducing border length to one half increases the cost because extra ditches are required to supply the extra borders. Using sprinkler irrigation in the high platforms increases the modernisation cost, but the resulting cost is much smaller than if sprinkler irrigation was used in the whole perimeter.

In Figures 7 to 9 the modernisation cost is plotted against each of the performance indexes. All scenarios present an improvement in average potential application efficiency (Figure 7), except for scenario I. The trend is for efficiency to grow linearly with the cost of the scenario, but scenario VII does not follow that trend: it represents an expensive option relatively to the gain in performance. Figure 8 presents a chart for decision support on modernisation projects. The planner can decide on the scenarios considering initial premises such as the maximum project cost or the minimum water savings needed. Decisions from the public offices to promote modernisation of certain districts using subsidies can be taken after exploring the total cost of the volume of water saved in different districts. Finally, Figure 9 presents a chart of cost vs. irrigation time. Farmers can locate in this chart options that help them reduce the time they dedicate to irrigation and relate these options to the cost of the required 
structures. In this case, scenarios VI and VII are not presented since they include sprinkler irrigation. When labour scarcity or cost is an issue, farmers will often prefer sprinkler irrigation.

\section{$\underline{\text { Summary and conclusions }}$}

The current performance of the Almudévar district is poor: potential application efficiency has been estimated as $54 \%$ using simulation, and the irrigation time is close to six hours per hectare. Some similarity has been found between the map of current $\mathrm{PAE}_{\mathrm{lq}}$ and the map of the Seasonal Irrigation Performance Index (SIPI) for corn (presented as figure 10a of the companion paper). The average corn SIPI was 50\%. The average application efficiency from the 14 irrigation evaluations was $62 \%$.

Irrigation water losses in the district are important, and the current irrigation practice does not satisfy the farmers. In surface irrigation, potential application efficiency has been shown to increase with irrigation discharge. This increase is not so

important beyond $100 \mathrm{~L} \mathrm{~s}^{-1}$. Irrigation time decreases drastically with the increase in discharge, reaching 1,5 hours per hectare for a discharge of $200 \mathrm{~L} \mathrm{~s}^{-1}$.

In the high platforms, $\mathrm{PAE}_{\mathrm{lq}}$ does not substantially increase with discharge. Even when the highest discharge is used, design units located in this area do not reach a 50\% efficiency. An attempt was made to increase surface irrigation efficiency in this area by reducing border length. This scenario effectively increased efficiency, but reducing border length would not be accepted in the context of Almudévar due to its interference with farm mechanisation. A new scenario was analysed, including solid set sprinkler 
irrigation in the platforms. The last scenario involved complete transformation to sprinkler irrigation.

The $200 \mathrm{ls}^{-1}$ full border irrigation and the full sprinkler irrigation scenarios are characterised by the same $\mathrm{PAE}_{\mathrm{lq}}(67 \%)$. The main difference between them is that the cost of the scenario considering only sprinkler irrigation is $65 \%$ higher. The best balance between cost and performance was found for the scenario involving $200 \mathrm{ls}^{-1}$ border irrigation in the valleys and sprinkler irrigation in the platforms. This scenario is characterised by the highest potential application efficiency (77\%) and a cost of 3,932 Euro ha ${ }^{-1}$, intermediate among the other two scenarios. This scenario has been evaluated as the best technical solution to the modernisation of the district. In fact, if this scenario was adopted, the expected water savings would be $14.410^{6} \mathrm{~m}^{3}$ per year. Most of the current water losses in the district are reused in other irrigation project districts. Consequently, the volume of water savings will not permit substantial increases of the irrigated area or crop intensity within the project. Among the most important consequences of these water savings are: 1) the improvement in the quality of surface waters, due to the reduction of irrigation return flows; and 2) the increase in the effective capacity of the project canals and reservoirs: the water that is actually bound to constitute return flows will not have to be stored at the main reservoir and conveyed through the canal network.

Use of sprinkler irrigation in the district will require on-farm investments whose cost will be largely dependent on the farm size, due to scale economies. Considering the current size of the average farm (around $3 \mathrm{ha}$ ) and the average holding (around $10 \mathrm{ha}$ ), it would be very expensive to modernise the area without concentrating the property so 
that the average farm reaches 10 ha. Independently of the irrigation system chosen for irrigation modernisation, internal reservoirs will have to be built to provide the required flexibility in the irrigation operation. This flexibility will contribute by itself to the improvement of irrigation efficiency, although the amount of this contribution is very difficult to foresee. The in-line reservoirs capacity should be added to that of the main reservoir when considering the project regulation capacity. If all districts in the project followed a modernisation scheme, the additional reservoir capacity would be very important.

In this paper, a simple procedure to assist decision making as related to irrigation modernisation has been presented and applied to the Almudévar irrigation district. This procedure has established a practical link between surface irrigation models, irrigation engineering and water planning activities. The analysis of the Almudévar district using the proposed techniques has been successful in the sense that the investment cost of the different scenarios has been related to water management parameters. The study could be presented in more depth, particularly with reference to cost analysis. In this report, only investment costs have been considered. An additional concern should be expressed here: the list of performance indexes used in figures 7,8 and 9 has been restricted to three. Other indexes of environmental or social nature should be added to enable appropriate decision making. Examples of such indexes would be the mass of salts or nitrates exported from the district via return flows, or farmer's acceptability of each scenario. Finally, the procedure here presented could be built into a software system capable of evaluating scenarios and establishing comparisons between them: such a product could be a valuable tool for professionals not necessarily acquainted with irrigation simulation. 


\section{Acknowledgements}

The authors would like to thank the management and farmers of the Almudévar

Irrigation District for their support. This work was sponsored in part by the INIA (Institute of Agricultural Research of the Government of Spain). The Mediterranean Agronomic Institute of Zaragoza (IAMZ-CIHEAM) awarded a scholarship to A. Slatni that made this research possible. 


\section{References}

Bucks, D. A. and Hunsaker, D. J. 1987. Water use variability in irrigated level basins. Trans. ASAE, 30(4):1090-1098.

Burt, C. M., Clemmens, A. J,. Strelkoff, T. S., Solomon, K. H., Bliesner, R. D., Hardy, L. A., Howell, T. A., Eisenhauer, D. E. 1997. Irrigation performance measures: efficiency and uniformity. J. Irrig. Drain. Engrg., ASCE, 123(6): 423-442.

Clemmens, A. J. 1987. Delivery system schedules and required capacities. In: Planning, operation, rehabilitation and automation of irrigation water delivery systems, Portland, Oregon, USA. pp. 18-34.

Comunidad de Regantes de Almudévar. 1997. Memoria de actividades. Almudévar, Huesca, Spain. 33 pp.

Cuenca, R. H. 1989. Irrigation system design: an engineering approach. Prentice-Hall, Inc., Englewood Cliffs, New Jersey. 552 pp.

Dedrick, A. R., Clyma, W., Tenney, O. L., Clemmens, A. J., Gibson, R. D., Levine, D. B., Replogle, J. A., Rish, S. A., Ware, R. E. and Wilson, P. N. 1993. A demonstration irrigation management improvement program. In: Fifteenth congress, International Commission on Irrigation and Drainage, The Hague, The Netherlands. pp. 95-104. 
Faci, J. M., Bensaci, A., Slatni, A. and Playán, E. 1999. A case study for irrigation modernisation: I. Characterisation of the district and analysis of water delivery records. Agric. Wat. Manag,, Submitted.

Isidoro, D., Trifol, F. and Quílez, D. 1997. Nitrógeno exportado por las aguas de drenaje de la Comunidad de Regantes de Almudévar (Monegros I, Huesca) durante el año hidrológico 1994-95. XV Congreso nacional de riegos, AERYD. Lleida, Spain. 269-278.

Merriam, J. L. and Keller, J. 1978. Farm irrigation system evaluation: a guide for management. Utah State University, Logan, Utah. 271 pp.

Quílez, D., Aragüés, R. and Faci, J. 1987. Calibración, verificación y aplicación de un modelo conceptual hidrosalino del sistema “flujos de retorno de riego”. Inv. Agr. Prod. Prot. Veg. 2(2):165-182.

Slatni, A. 1996. Elaboration et evaluation des alternatives por l'amélioration de l'utilisation de l'eau au sein de la communauté d'irrigants d'Almudévar. MSc thesis, Instituto Agronómico Mediterráneo de Zaragoza, Spain (CIHEAM). 132 pp.

Torres, M. 1983. Balance hidrosalino de un poligono de riego en los llanos de la Violada (Huesca). Master thesis, Instituto Agronómico Mediterráneo de Zaragoza (CIHEAM). 274 pp. 
Walker, W. R., 1989. Guidelines for designing and evaluating surface irrigation systems. Food and Agriculture Organisation (FAO). Irrig. and Drain. Paper 45, Rome, Italy, 137 pp.

Walker, W. R. 1993. SIRMOD, Surface irrigation simulation software. Utah State University. Logan, Utah. 27 pp. 


\section{$\underline{\text { Tables }}$}

Table 1. Modernisation investment costs considered in the economical analysis of the scenarios.

Cost

Low pressure concrete pipes, including turnouts, checks and measurement devices:

$\phi 400 \mathrm{~mm}$, for $50 \mathrm{~L} \mathrm{~s}^{-1}$

43.3 Euro $\mathrm{m}^{-1}$

$\phi 500 \mathrm{~mm}$, for $100 \mathrm{~L} \mathrm{~s}^{-1}$ 51.6 Euro $\mathrm{m}^{-1}$

$\phi 600 \mathrm{~mm}$, for 150 and $200 \mathrm{~L} \mathrm{~s}^{-1}$ 59.3 Euro $^{-1}$

Reservoir construction..... 2.7 Euro $\mathrm{m}^{-3}$

On-farm sprinkler irrigation system, buried solid set... 2,669 Euro ha ${ }^{-1}$

Pumping stations, reservoirs, distribution pipes and valves, for sprinkler irrigation systems:

Scenario VI: 2,479 Euro ha ${ }^{-1}$

Scenario VII: 2,185 Euro ha ${ }^{-1}$ 
Table 2. Irrigation evaluation results. $Q$, irrigation discharge; $t_{c}$, irrigation time; SDe, standard deviation of soil surface elevation; $n$, Manning roughness parameter; $k$ and $a$, Kostiakov infiltration parameters; $D U_{l q}$, distribution uniformity of the low quarter; and $A E$, application efficiency.

\begin{tabular}{|c|c|c|c|c|c|c|c|c|c|c|c|c|c|}
\hline $\begin{array}{c}\text { Evaluation } \\
\#\end{array}$ & Crop * & $\begin{array}{c}\text { Soil } \\
\text { depth } \\
(\mathrm{cm})\end{array}$ & $\begin{array}{l}\text { Slope } \\
(\%)\end{array}$ & $\begin{array}{l}\text { Area } \\
\left(\mathrm{m}^{2}\right)\end{array}$ & $\begin{array}{l}\text { Length } \\
\text { (m) }\end{array}$ & $\begin{array}{c}Q \\
\left(\mathrm{~L} \mathrm{~s}^{-1}\right)\end{array}$ & $\begin{array}{c}t_{c} \\
(\mathrm{~min})\end{array}$ & $\begin{array}{l}\text { SDe } \\
\text { (cm) }\end{array}$ & $n$ & $\begin{array}{c}k \\
\left(\mathrm{~m} \min ^{-}\right. \\
\left.{ }^{\mathrm{a}}\right)\end{array}$ & $\mathrm{a}$ & $\begin{array}{l}D U_{l q} \\
(\%)\end{array}$ & $\begin{array}{l}A E \\
(\%)\end{array}$ \\
\hline 1 & Corn & 100 & 0.60 & 8,772 & 204 & 53,9 & 265 & 1,23 & 0,04 & 0,017 & 0,33 & 90 & 71,1 \\
\hline 2 & Alfalfa, 5 cm & 80 & 0.60 & 7,006 & 308 & 118,0 & 227 & 1,00 & 0,14 & 0,016 & 0,45 & 58,5 & 29,2 \\
\hline 3 & Alfalfa, $25 \mathrm{~cm}$ & 80 & 1.00 & 8,593 & 168 & 79,0 & 194 & 1,20 & 0,29 & 0,017 & 0,33 & 77,7 & 69,7 \\
\hline 4 & Corn & 100 & $\mathrm{C}$ & 5,215 & 140 & 25,0 & 500 & 1,30 & 0,06 & 0,012 & 0,30 & 73,0 & 79,0 \\
\hline 5 & Alfalfa, $40 \mathrm{~cm}$ & 120 & 0.60 & 4,494 & 107 & 124,0 & 61 & 3,40 & 0,25 & 0,008 & 0,50 & 93,7 & 63,4 \\
\hline 6 & Alfalfa, $40 \mathrm{~cm}$ & 100 & 0.23 & 2,394 & 114 & 35,2 & 165 & 1,80 & 0,25 & 0,034 & 0,20 & 98,9 & 48,3 \\
\hline 7 & Alfalfa, $15 \mathrm{~cm}$ & 40 & 0.10 & 13,215 & 190 & 125,6 & 240 & 1,50 & 0,25 & 0,004 & 0,50 & 88,4 & 90,0 \\
\hline 8 & Alfalfa, $15 \mathrm{~cm}$ & 110 & 1.50 & 4,413 & 145 & 25,4 & 327 & 2,40 & 0,15 & 0,010 & 0,41 & 97,8 & 61,6 \\
\hline 9 & Alfalfa, $15 \mathrm{~cm}$ & 110 & 0.20 & 11,147 & 157 & 68,0 & 251 & 2,66 & 0,06 & 0,005 & 0,35 & 85,6 & 84,0 \\
\hline 10 & Alfalfa, 5 cm & 110 & 0.85 & 21,525 & 105 & 64,3 & 94 & 3,90 & 0,25 & 0,013 & 0,50 & 94,6 & 41,5 \\
\hline 11 & Alfalfa, 5 cm & 50 & 2.00 & 3,676 & - & 10,6 & 240 & 3,50 & - & - & - & - & - \\
\hline 12 & Alfalfa, 5 cm & 110 & 1.20 & 8,930 & 380 & 64,0 & 328 & 1,80 & 0,10 & 0,020 & 0,33 & 97,9 & 49,6 \\
\hline 13 & Alfalfa, $5 \mathrm{~cm}$ & 80 & 0.80 & 9,248 & 175 & 106,0 & 117 & 0,90 & 0,10 & 0,018 & 0,32 & 99,8 & 64,9 \\
\hline 14 & Alfalfa, $5 \mathrm{~cm}$ & 110 & 0.80 & 3,475 & 139 & 51,0 & 155 & 1,70 & 0,12 & 0,020 & 0,35 & 93,7 & 50,7 \\
\hline 15 & Corn & 40 & 0.80 & 5,510 & 103 & 87,0 & 120 & 1,60 & 0,06 & 0,012 & 0,45 & 90,9 & 60,0 \\
\hline Average & - & 89 & 0.80 & 6,974 & 174 & 69.1 & 219 & 1.99 & 0.15 & $0.015^{* *}$ & $0.38 * *$ & 88.6 & 61.6 \\
\hline
\end{tabular}


Table 3. Simulation results: average irrigation time $\left(t_{c}\right)$, potential application efficiency of the low quarter $\left(P A E_{l q}\right)$ and distribution uniformity of the low quarter $\left(D U_{l q}\right)$ for each scenario.

\begin{tabular}{cccc}
\hline Scenario & $\begin{array}{c}t_{c} \\
\left(\mathrm{~min} \mathrm{ha}^{-1}\right)\end{array}$ & $\begin{array}{c}P A E_{l q} \\
(\%)\end{array}$ & $\begin{array}{c}D U_{l q} \\
(\%)\end{array}$ \\
\hline I & 537 & 49 & 82 \\
II & 209 & 59 & 89 \\
III & 124 & 64 & 92 \\
IV & 87 & 67 & 92 \\
V & 77 & 71 & 92 \\
VI & - & 77 & 88 \\
VII & - & $67^{*}$ & $82^{*}$ \\
\hline
\end{tabular}

* Average value (Cuenca, 1989) for solid set sprinkler irrigation in a semiarid climate 
Table 4. Volumes of irrigation requirements, water savings and required reservoir capacity for each scenario.

\begin{tabular}{cccc}
\hline Scenario & $\begin{array}{c}\text { Gross irrigation } \\
\text { requirements } \\
10^{6} \mathrm{~m}^{3} \text { year }^{-1}\end{array}$ & $\begin{array}{c}\text { Water } \\
\text { savings } \\
10^{6} \mathrm{~m}^{3} \mathrm{year}^{-1}\end{array}$ & $\begin{array}{c}\text { Night } \\
\text { Reservoir* } \\
10^{6} \mathrm{~m}^{3}\end{array}$ \\
\hline Current & 48.4 & - & - \\
I & 53.3 & -4.9 & 0.244 \\
II & 44.2 & 4.2 & 0.185 \\
III & 40.8 & 7.6 & 0.163 \\
IV & 39.0 & 9.4 & 0.150 \\
V & 36.8 & 11.6 & 0.124 \\
VI & 34.0 & 14.4 & 0.068 \\
VII & 39.0 & 9.4 & - \\
\hline
\end{tabular}

* Only for surface irrigated areas 
Table 5. Estimates of modernisation costs for each scenario.

\begin{tabular}{cc}
\hline Scenario & $\begin{array}{c}\text { Total modernisation } \\
\text { cost } \\
\left(\text { Euro ha }^{-1}\right)\end{array}$ \\
\hline I & 2,402 \\
II & 2,781 \\
III & 3,155 \\
IV & 3,149 \\
V & 3,890 \\
VI & 3,932 \\
VII & 5,195 \\
\hline
\end{tabular}




\section{Figures}

Figure 1. Infiltration curves corresponding to the irrigation evaluations (symbols) and infiltration classes (lines).

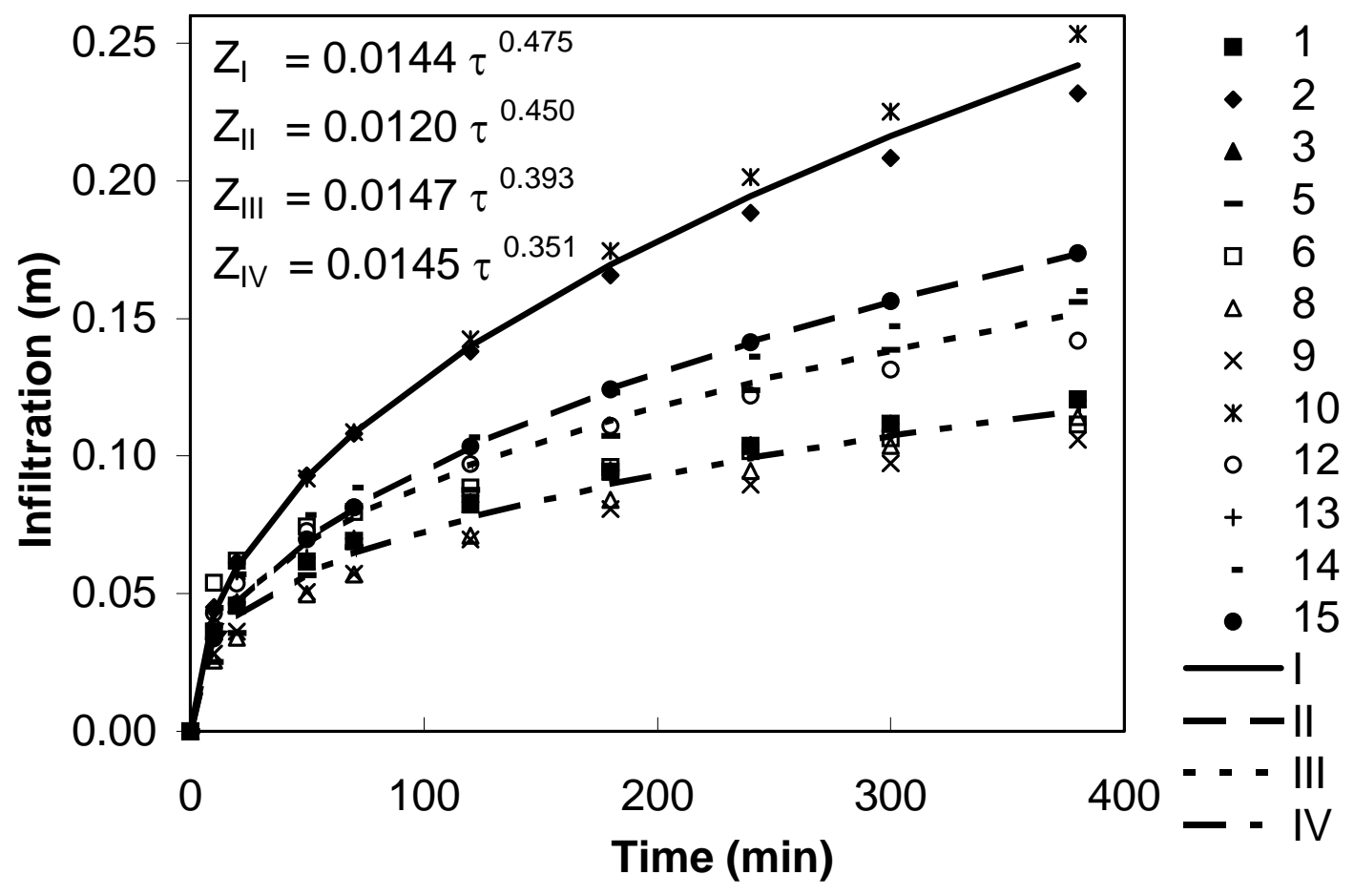


Figure 2. Almudévar irrigation district design units map.

Axes values in UTM co-ordinates.

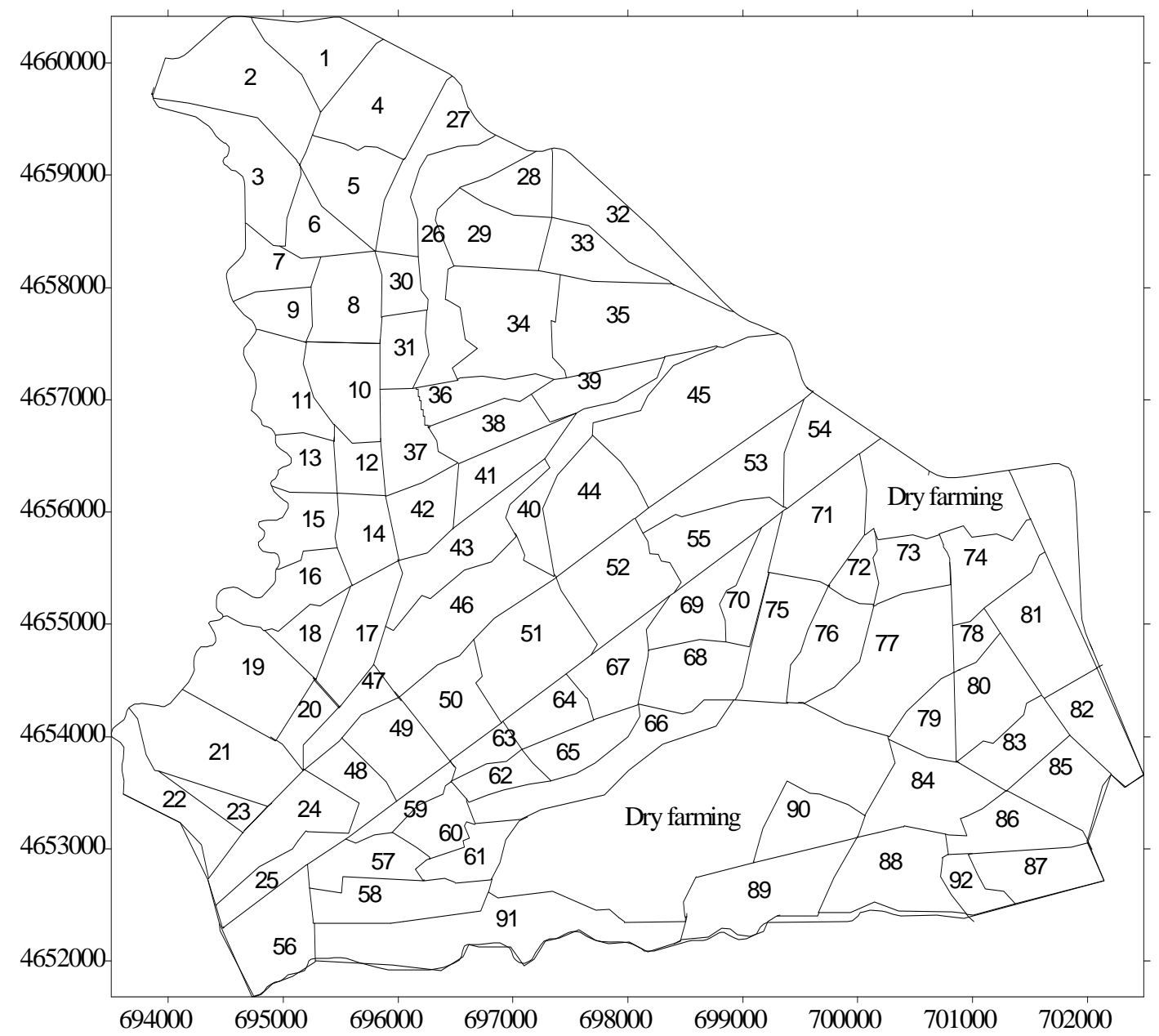


Figure 3. Contour map of current potential application efficiency of the low quarter (\%). Axes values in UTM co-ordinates.

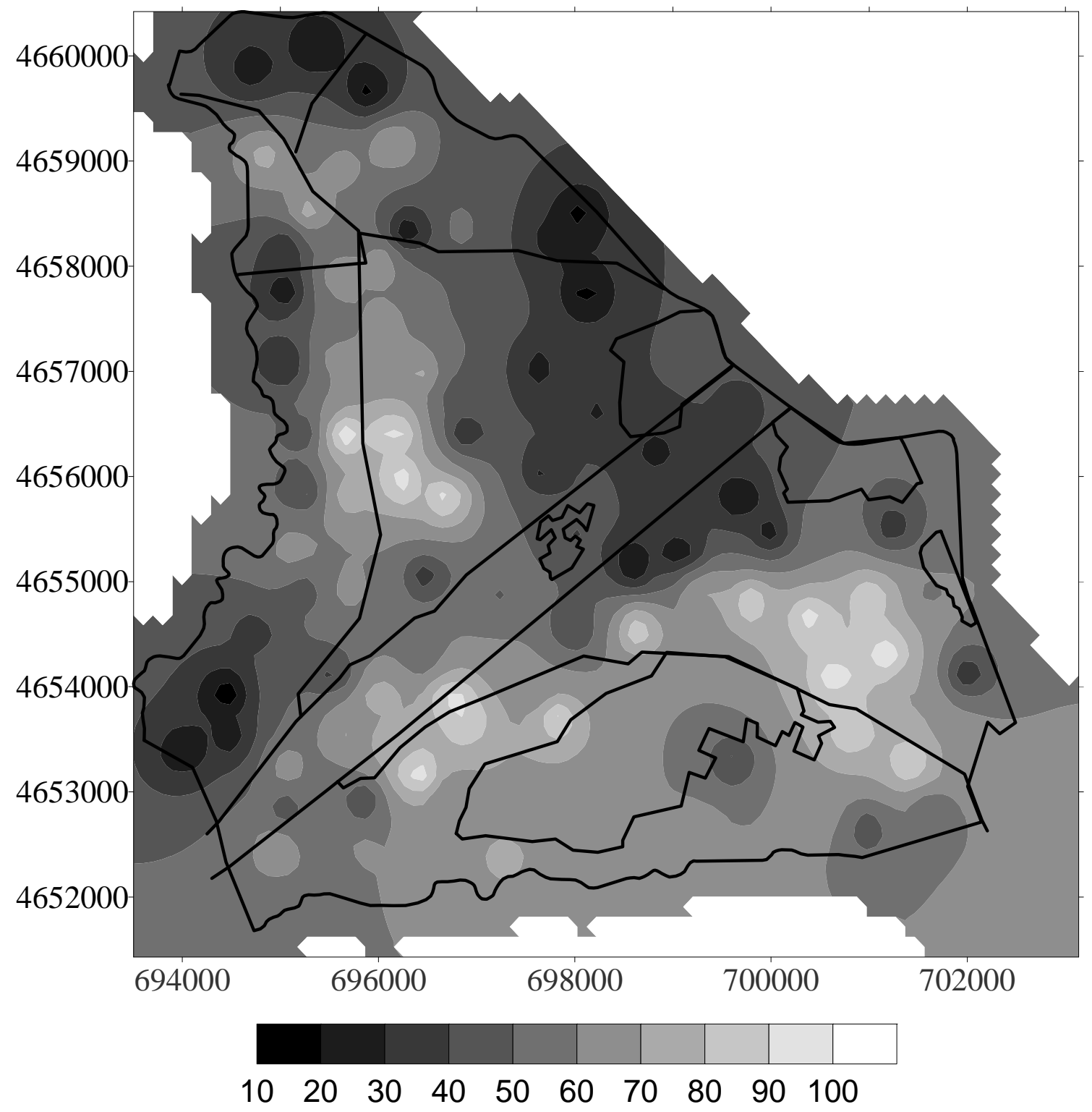


Figure 4. Contour map of current irrigation time ( $\left.\mathrm{min} \mathrm{ha}^{-1}\right)$.

Axes values in UTM co-ordinates.

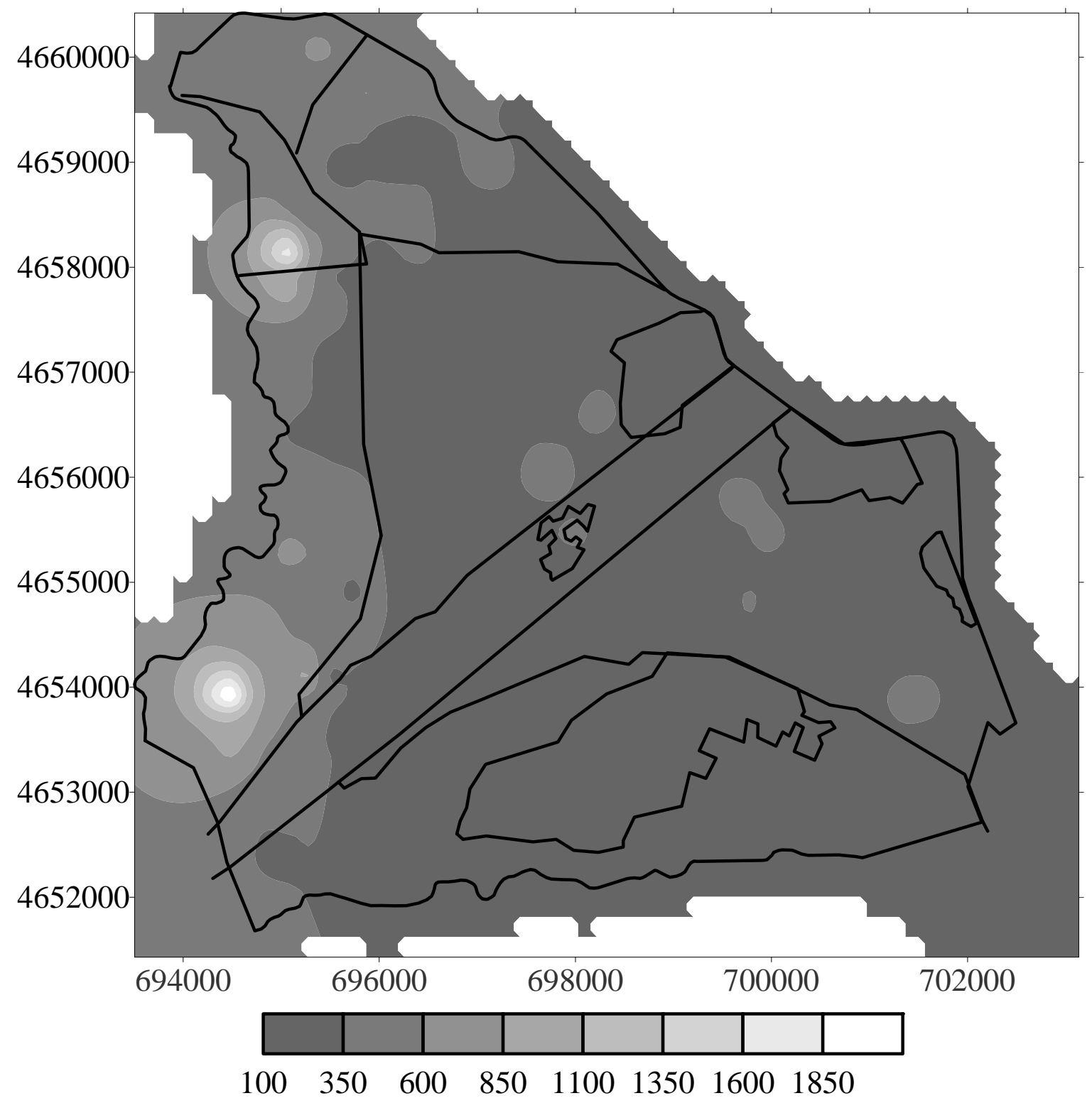


Figure 5. Contour map of potential application efficiency of the low quarter (\%) for scenario IV (discharge of $200 \mathrm{~L} \mathrm{~s}^{-1}$ ). Axes values in UTM coordinates.

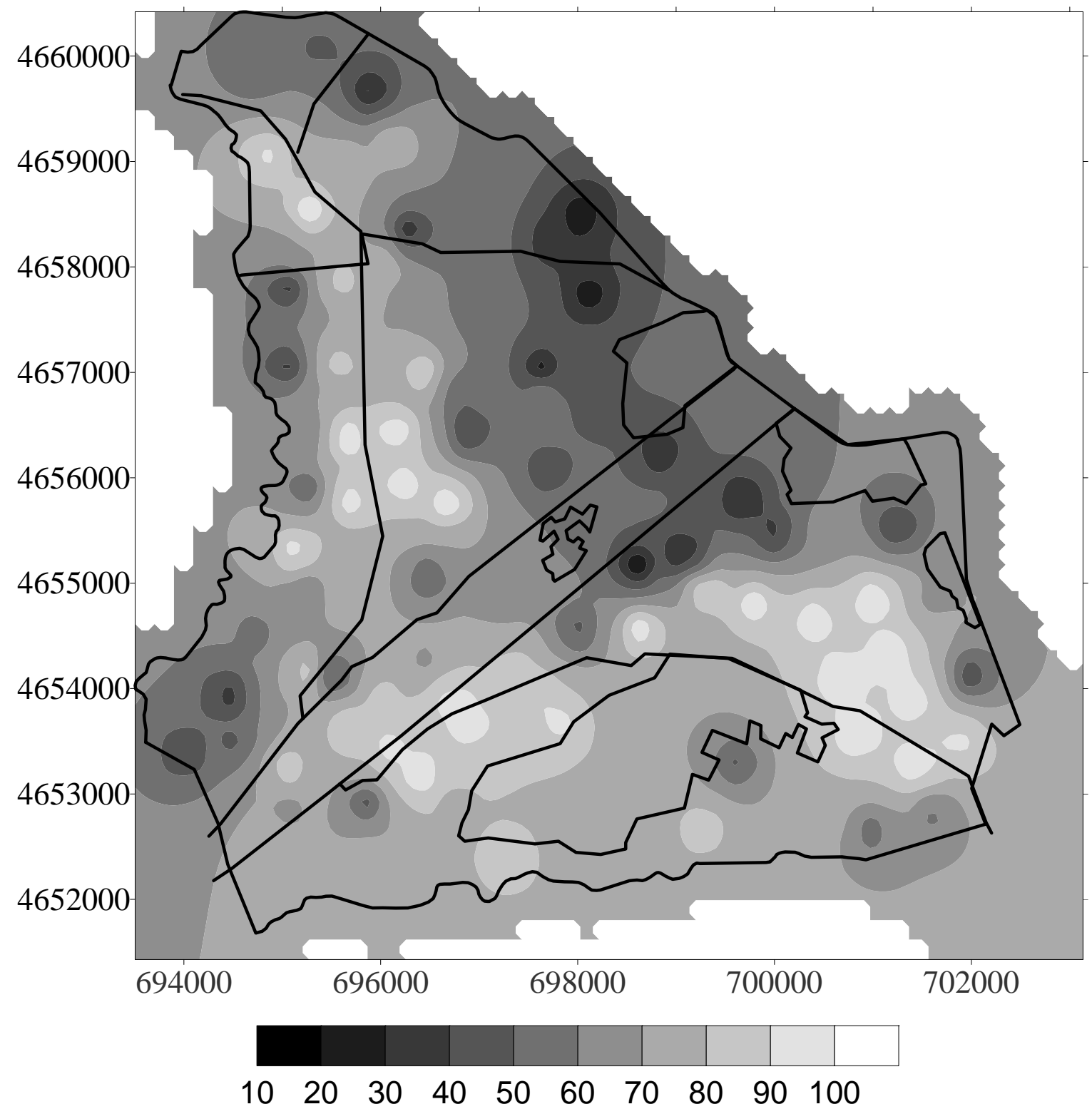


Figure 6. Contour map of potential application efficiency of the low quarter (\%) for scenario VI (surface irrigation with a discharge of $200 \mathrm{~L} \mathrm{s-1}$ for those design units attaining irrigation efficiencies over $50 \%$; sprinkler irrigation for the rest). Axes values in UTM co-ordinates.

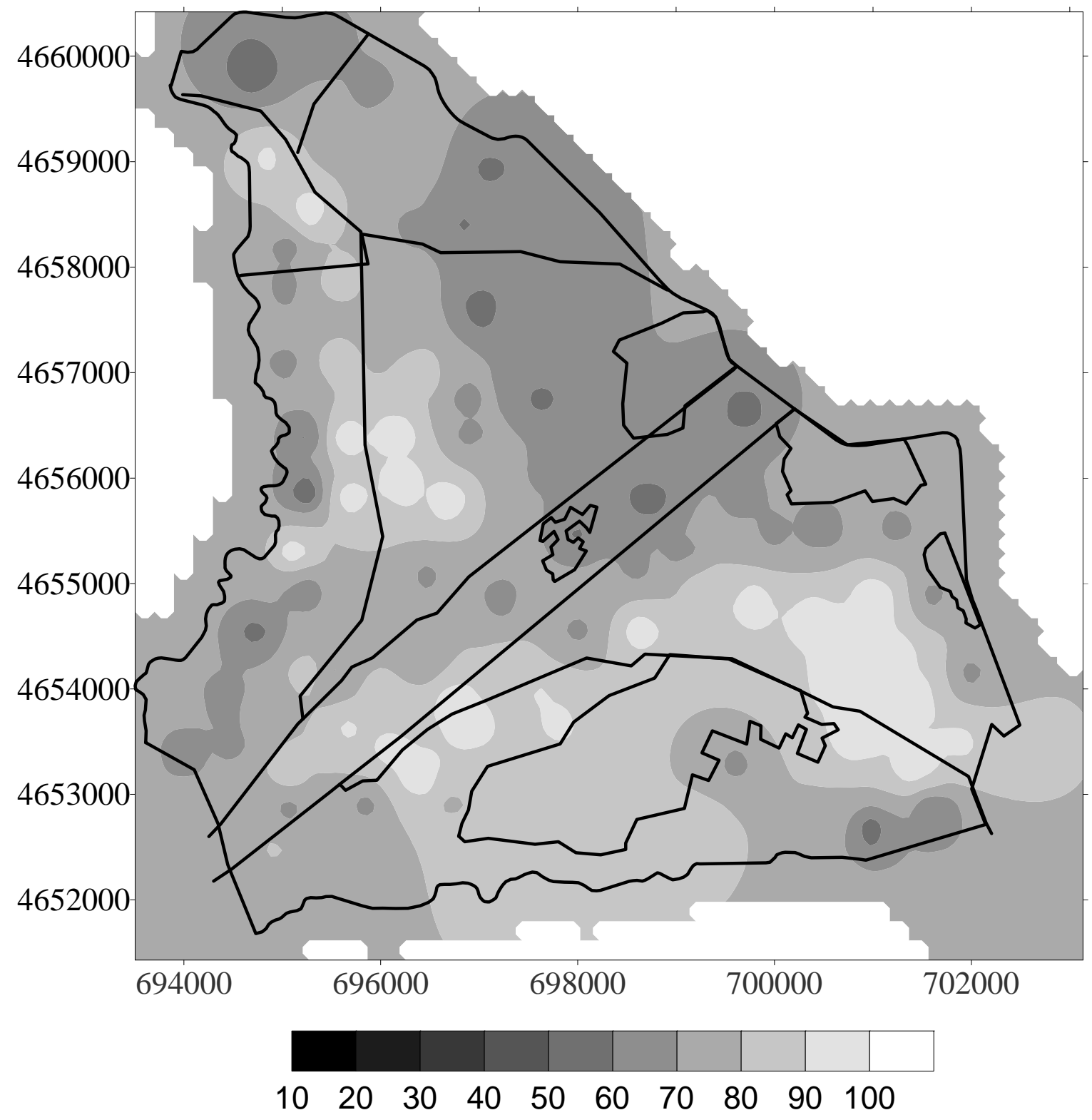


Figure 7. Average potential application efficiency of the low quarter vs. modernisation cost for each scenario.

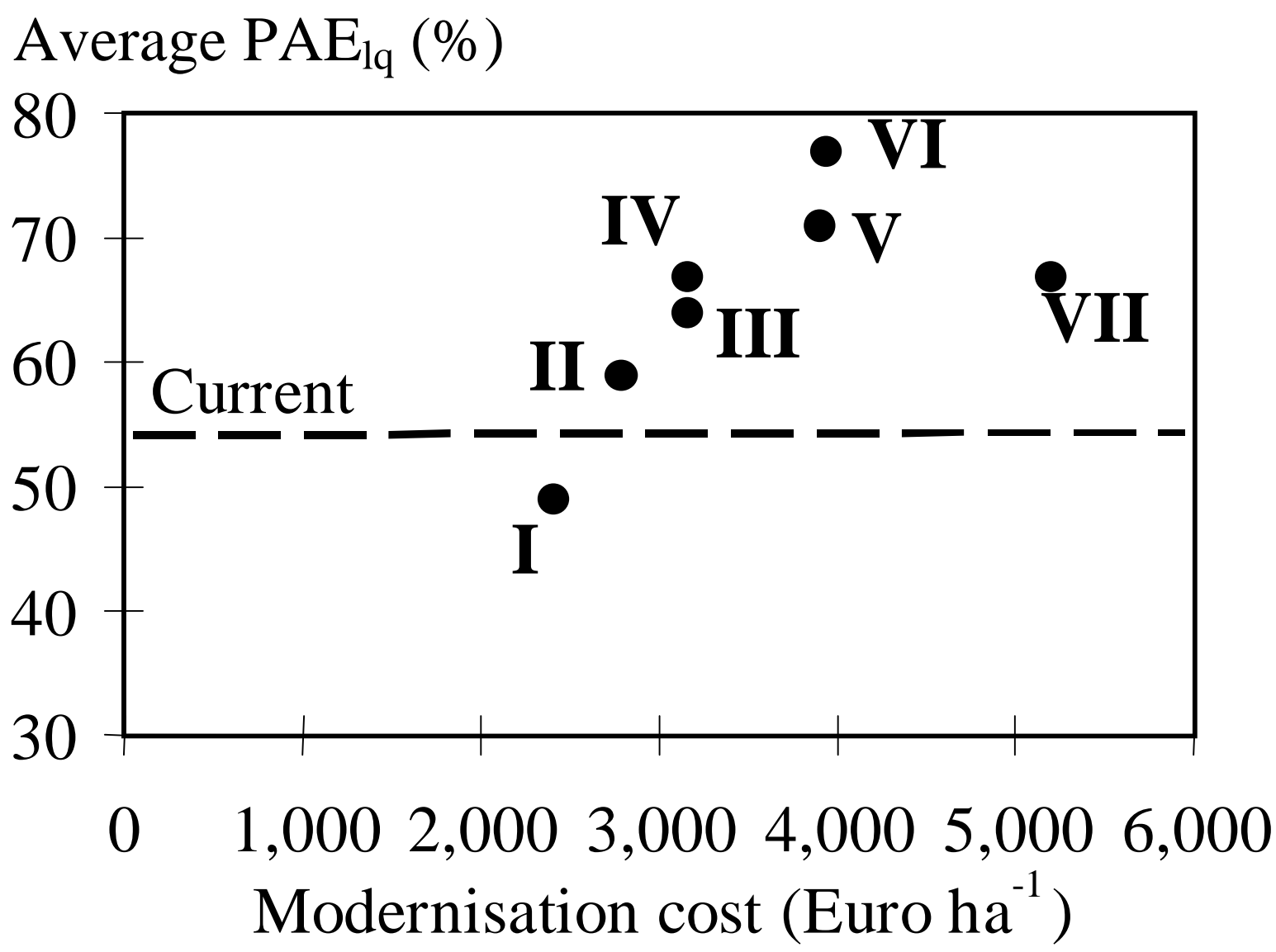


Figure 8. Irrigation water savings vs. modernisation cost for each scenario.

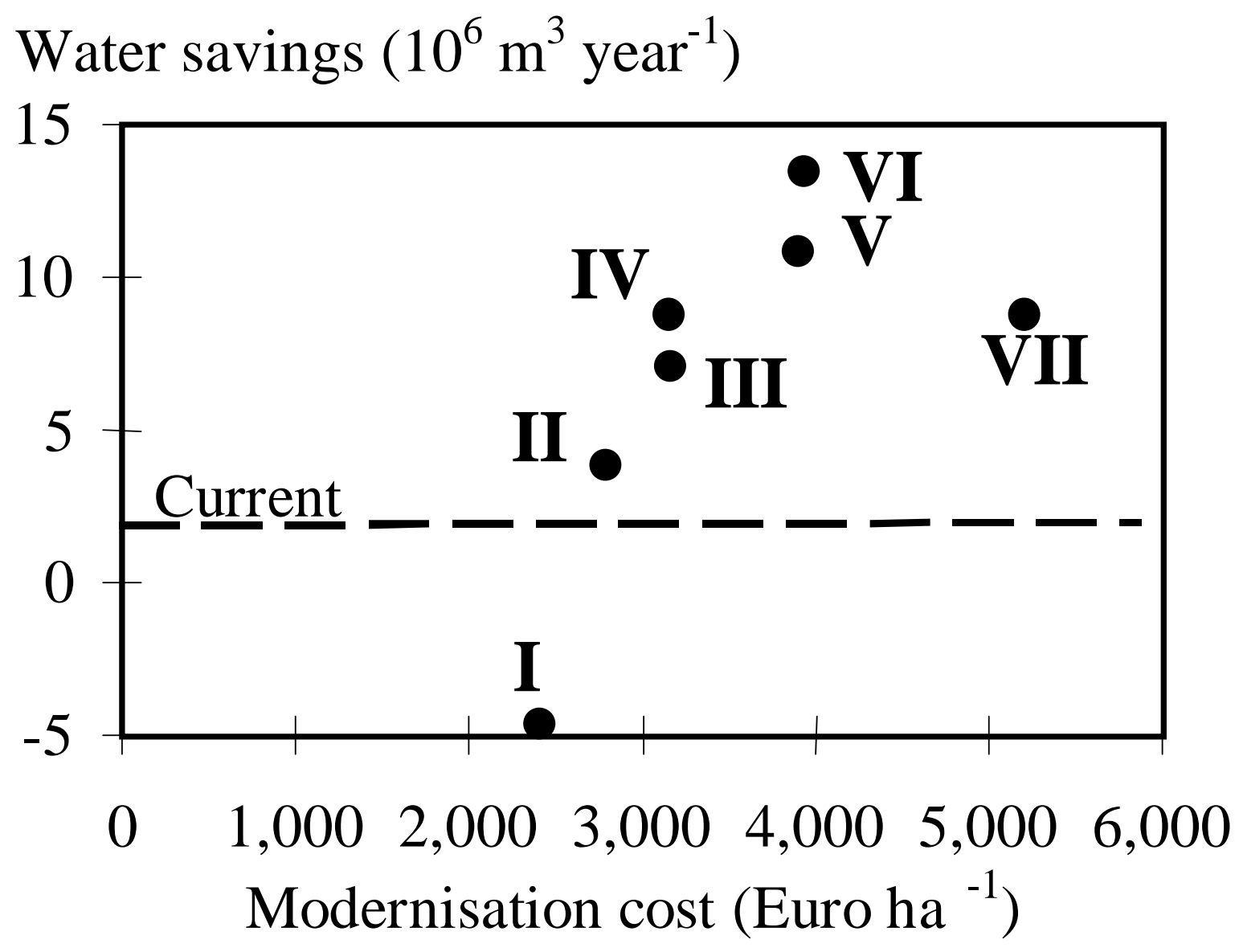


Figure 9. Irrigation time vs. modernisation cost for each scenario based entirely on surface irrigation.

Irrigation time (min ha ${ }^{-}$

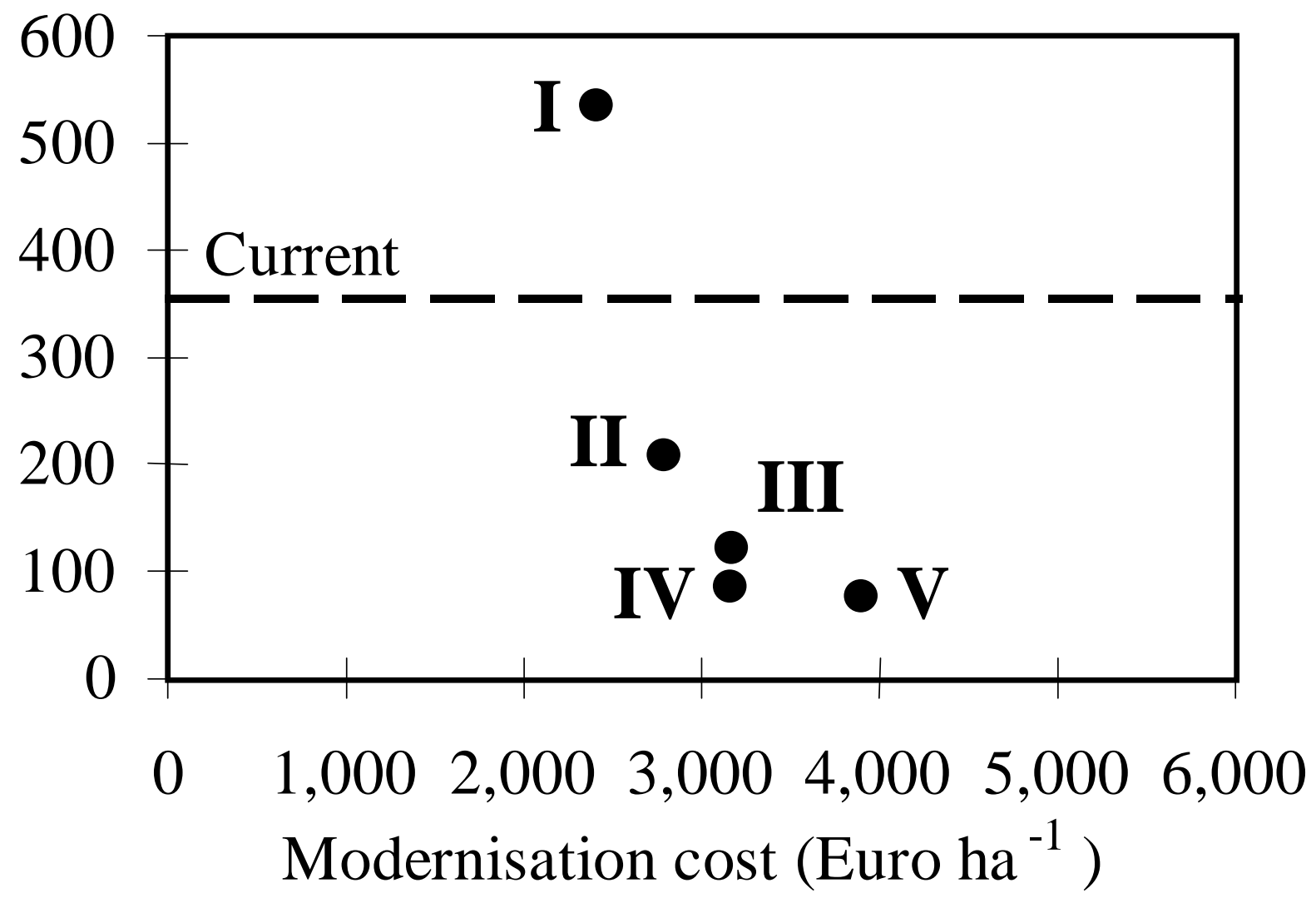

